International Center for Public Policy

Working Paper 16-05

March 2016

Taxing Consumption in Canada: Rates, Revenues, and Redistribution

\author{
Richard Bird \\ Michael Smart
}



International Center for Public Policy

Working Paper 16-05

\section{Taxing Consumption in Canada: Rates, Revenues, and Redistribution}

Richard Bird

Michael Smart

March 2016 


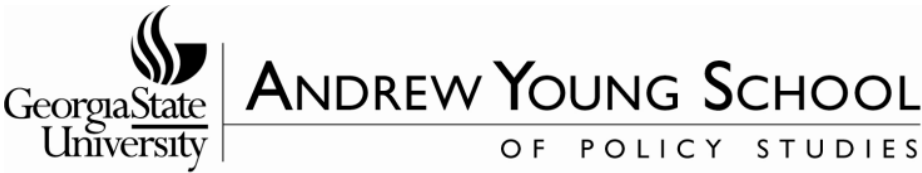

\section{International Center for Public Policy Andrew Young School of Policy Studies}

The Andrew Young School of Policy Studies was established at Georgia State University with the objective of promoting excellence in the design, implementation, and evaluation of public policy. In addition to two academic departments (economics and public administration), the Andrew Young School houses seven leading research centers and policy programs, including the International Center for Public Policy.

The mission of the International Center for Public Policy is to provide academic and professional training, applied research, and technical assistance in support of sound public policy and sustainable economic growth in developing and transitional economies.

The International Center for Public Policy at the Andrew Young School of Policy Studies is recognized worldwide for its efforts in support of economic and public policy reforms through technical assistance and training around the world. This reputation has been built serving a diverse client base, including the World Bank, the U.S. Agency for International Development (USAID), the United Nations Development Programme (UNDP), finance ministries, government organizations, legislative bodies and private sector institutions.

The success of the International Center for Public Policy reflects the breadth and depth of the in-house technical expertise that the International Center for Public Policy can draw upon. The Andrew Young School's faculty are leading experts in economics and public policy and have authored books, published in major academic and technical journals, and have extensive experience in designing and implementing technical assistance and training programs. Andrew Young School faculty have been active in policy reform in over 40 countries around the world. Our technical assistance strategy is not to merely provide technical prescriptions for policy reform, but to engage in a collaborative effort with the host government and donor agency to identify and analyze the issues at hand, arrive at policy solutions and implement reforms.

The International Center for Public Policy specializes in four broad policy areas:

- Fiscal policy, including tax reforms, public expenditure reviews, tax administration reform

- Fiscal decentralization, including fiscal decentralization reforms, design of intergovernmental transfer systems, urban government finance

- Budgeting and fiscal management, including local government budgeting, performancebased budgeting, capital budgeting, multi-year budgeting

- Economic analysis and revenue forecasting, including micro-simulation, time series forecasting,

For more information about our technical assistance activities and training programs, please visit our website at http://aysps.gsu.edu/isp/index.html or contact us by email at gbotello1@gsu.edu 


\title{
Taxing Consumption in Canada: Rates, Revenues, and Redistribution
}

\author{
Richard Bird \\ Michael Smart \\ University of Toronto
}

March 2016

\begin{abstract}
The introduction of the VAT in Canada, initially in the form of the federal GST in 1991, did not signify a major change in the tax mix even after most provincial sales taxes also became VATs. Canadians do not pay much if any more in taxes on their consumption than they did 25 years ago. Although the GST and its provincial companions are not perfect, the evidence is that they create fewer barriers to investment and growth than the taxes they replaced so that Canadians appear as a whole to be better off than they were before setting off down the road to VAT. Nonetheless, perhaps in part because the VAT in Canada unlike in other countries is generally quoted separately (like retail sales taxes in the US) and hence highly visible, it continues to be politically unpopular and considered undesirably regressive.

The major contribution of this paper is to examine in some detail and with some new evidence the incidence of Canada's sales and excise taxes, a question that has received surprisingly little analysis. Because the share of total consumption taxes coming from sales rather than excise taxes has increased, these taxes are now less regressive than they were before the move to VAT, regardless of how incidence is measured. More importantly, there are solid arguments for using consumption than income as a basis for evaluating the progressivity of consumption taxes, and on this measure the GST and its companion taxes appear to be mildly progressive. However because the remaining excises are quite regressive even on this basis, on the whole the sales and excise system remains mildly regressive.
\end{abstract}

JEL codes: $\mathrm{H} 22, \mathrm{H} 25$

Key words: sales tax, excise tax, value-added tax, incidence, progressivity 


\title{
Taxing Consumption in Canada: Rates, Revenues, and Redistribution
}

\author{
Richard Bird \\ Michael Smart \\ University of Toronto
}

March 2016

\section{Introduction}

Canada's system of sales taxation is complex. The Goods and Services Tax (GST), its federal value added $\operatorname{tax}$ (VAT), is levied at a headline rate of 5 per cent, which is the lowest national VAT rate of any country in the world. ${ }^{1}$ On the other hand, unlike in any other country, the federal VAT is supplemented by subnational VATs - the Quebec Sales Tax (QST) in Quebec and the Harmonized Sales Tax in five other provinces $^{2}$-- and separately administered retail sales taxes (RSTs) in three other provinces. ${ }^{3}$ In addition, the federal government and each of the provinces impose additional taxes on some or all of the traditional 'excisable' goods - alcohol, tobacco and motive fuels. ${ }^{4}$ The result is a system of sales and excise taxation that is larger and has greater economic effect than a simple focus on the federal GST would initially suggest. ${ }^{5}$

\footnotetext{
${ }^{1}$ VAT is also levied in Nigeria and Taiwan at a basic rate of 5 per cent, although the fall in oil prices has recently led to proposals to raise the rate to 10 per cent in Nigeria.The VAT rate in Japan, which was initially 5 per cent, was raised to 8 per cent in 2013 and is scheduled to rise to 10 per cent in 2017.

2 The federal VAT is administered by the province together with QST in Quebec; the provincial component of HST is administered by the federal government in the five participating HST provinces, which are Ontario, New Brunswick, Nova Scotia, Prince Edward Island, and Newfoundland and Labrador. Two other countries, Brazil and India, have subnational VATs, but they are very different from the Canadian system of independent but largely integrated federal and provincial VATs (Bird 2015a).

${ }^{3}$ These are Manitoba, Saskatchewan, and British Columbia. The province of Alberta and the three northern territories have no general sales tax at all, although the CRA administers the GST in Alberta as well as in the provinces that have RSTs. The CRA also administers sales taxes on behalf of a number of First Nations. As of December 2015, 28 governing bodies of First Nations - mostly located in British Columbia and Yukon -- had imposed the First Nations Goods and Services Tax (FNGST) and signed agreements with the CRA to administer the tax, which is in effect the same as the federal GST, on their behalf. In addition, the CRA administers the First Nations Tax (FNT) - again at the rate of the GST (the federal part of the HST) - on specified tobacco, alcohol and fuel products for an additional eight First Nations, all in British Columbia. (Information from http://www.craarc.gc.ca/ accessed on February 25, 2016). These taxes are not further discussed here, however.

${ }^{4}$ A few minor indirect taxes (e.g. on insurance premiums, automobile air conditioners, and taxes on amusement and hotel rooms) are not further discussed here.

${ }^{5}$ Most of these taxes are included in the base on which the general sales tax is levied when that tax takes the form of a VAT (i.e., the GST, HST, and QST). However, in some provinces with retail sales taxes some goods subject to excise taxes are not subject to provincial sales taxes: for example, in Manitoba and Saskatchewan gasoline is exempt from sales tax although tobacco is taxed.
} 
Although significant revenue is still raised by excise taxes, especially at the provincial level, the general sales taxes noted above (GST, QST, HST, and RSTs) are considerably more important, and they are the main focus of this article. These taxes have long been controversial in political and economic discussions of tax policy in Canada. When the federal government reduced the rate of the GST in 2006 and then again in 2008, many economists suggested that it would be more appropriate to increase rather than reduce its taxation of consumption. ${ }^{6}$ The basic argument in favour of VAT, based on both theory and empirical evidence, is that taxes imposed on consumption impose lower social costs -- in the form of distorting economic decisions - than taxes on income. ${ }^{7}$ However, it is perhaps not surprising that arcane calculations based on esoteric models are not found persuasive by most Canadians who - unlike their generally more heavily taxed counterparts in most other developed countries - are faced daily with the very visible GST/HST and hence highly conscious of its apparent impact on their daily living costs. ${ }^{8}$ Similarly, when British Columbia, which had moved from an RST to the HST in 2010, decided to return to the RST in 2013 most economists were unhappy, arguing that a value-added tax like the HST was far superior to a "retail" sales tax that in fact fell substantially on business and investment expenditures. ${ }^{9}$ In the face of substantial public opposition, however, the economists lost both arguments: the GST rate was cut from 7 percent to 5 percent, and BC returned to its old sales tax. ${ }^{10}$ With the recent change in government federally and the possible emergence of long-term "structural" deficits at the federal level, however, there have been renewed calls by some for an increase in the GST rate.

This paper seeks to provide some facts to those involved in these debates, by detailing the role of sales and excise taxes in government revenues and in the Canadian economy. We present data on statutory sales tax rates and on the share of sales and excise taxes in GDP and in government revenues, and we show how these shares have evolved over the past 35 years. We then turn our focus to the distributional effects of sales and excise taxes. Perhaps the major reason why Canadians have been so reluctant to move towards heavier reliance on consumption taxes is because most believe that such taxes are regressive, with the tax burdens disproportionately borne by low-income households rather than high-income households. We explore this question using cross-sectional data on consumption patterns and tax payments of Canadian households and argue that the presumed regressivity of sales taxes - particularly general sales taxes like the GST - is far from clear.

\section{Rates and Revenues}

Table 1 contains the nominal rates of general sales taxes in the year in which they were introduced in their current form and in 2015 as well as a brief summary of the major changes in these rates over time.

Two interesting points emerge from this table. The first is that, as already noted, most general sales

\footnotetext{
${ }^{6}$ See Kesselman and Spiro (2014) for one notable exception.

${ }^{7}$ For example, Baylor and Beausejour (2004) estimated that reducing income taxes by a given amount would be more than twice as beneficial to Canadians as a whole as an equivalent reduction in taxes on consumption. Consistent with the theory, Smart and Bird (2009a) find that the 1997 reform introducing VAT in some Canadian provinces led to an increase in business investment. Similar results emerge from many other studies in a variety of countries: for a useful review, see Johansson et al. (2008).

${ }^{8}$ As we have argued elsewhere, this impact is more apparent than real (Smart and Bird, 2009b); but it is nonetheless clearly visible - and much more so in Canada than in any other country with a VAT (Bird 2010).

${ }^{9}$ As Kuo, McGirr, and Poddar (1988) conclusively demonstrated long ago for Canada.

${ }^{10}$ For interesting perspectives on the British Columbia case, see Richards (2012) and Robertson (2012).
} 
taxes in Canada are now value-added taxes (VATs). Since these taxes -- GST,HST, QST ${ }^{11}$ - probably accounted for close to 90 percent of sales taxes collected in 2014, with the balance coming from the retail sales taxes still applied in three western provinces ${ }^{12}$ - it seems reasonable to treat all sales taxes as based on final consumption as we do in the subsequent discussion of the incidence of these taxes. ${ }^{13}$

The second and more important point is that although over time nominal sales tax rates have tended to increase there have been some exceptions, with by far the most important being the cut in the federal GST rate in 2006 and again in 2008. This rate reduction definitely reduced the importance of federal consumption taxes. McKenzie (2015) has recently discussed how, despite the marked reduction in corporate tax rates, income tax revenues have increased in recent decades. Indeed, to a large extent income taxes financed the expansion of government activity detailed in Milligan (2014). In contrast, as Figure 1 shows, Canadian governments as a whole now rely less heavily on sales and excise taxes for revenue (25.5 per cent of tax revenue in 2014) than they did when the GST was first introduced in 1991 (26.9 per cent) and little more than was the case in 1981 (24.9 per cent). The main conclusion suggested by Figure 1 is thus that - although tax burdens rose to new heights in the late 1980s before falling substantially in the first decade of this century - the share of taxes falling on consumption has been close to constant over time. There has been little change in the level or importance of consumption as a source of government revenue in Canada. Although federal sales tax revenues did expand slightly following the introduction of the GST (prior to the rate cut) the VAT has clearly not been the 'money machine' that some feared - and others perhaps hoped - at the time of its introduction. ${ }^{14}$

Table 2 provides a summary picture of trends in sales and excise taxes over the last 35 years. Figures 2 and 3 depict the changing composition of revenues from these taxes at the federal and provincial levels. As Figure 2 shows, the most dramatic change at the federal level has been the substantial decline in the importance of import duties as a source of revenue, from 6.1 per cent of total federal taxes (and 30.6 per cent of sales and excise revenue) in 1981 to less than 2 per cent of total taxes (and less than 10 per cent of sales and excise taxes) in each of the last 20 years. In contrast, federal taxes on gasoline and other motive fuels rose substantially to over 3 per cent of total revenues in the early 1990s before declining to little more than 2 per cent in the present century. Other federal excises (mainly on alcoholic beverages) ended the period as they began it, accounting for about 2 per cent of total taxes and 10 per cent of sales and excise revenue. The changes at the federal level are dominated by the sharp increase in revenues from the pre-GST federal sales tax (the MST) in the 1980s ending with a sharp decline in 1990 which was then largely recouped by the introduction of the GST in 1991. The importance of the GST then remained fairly constant at around 15 per cent of total taxes until it rose sharply to over 17 per cent in the early years of the present century and was then reduced by the rate cuts mentioned earlier to its more or less steady recent level of 14 per cent of total federal taxes.

\footnotetext{
${ }^{11}$ The QST is also often called the TVQ (taxe de vente du Québec).

12 This share is estimated on the detailed basis of 2009 provincial data in Treff and Ort (2011).

${ }^{13}$ This assumption is not entirely correct, however, not only because the remaining RSTs are imposed to a significant extent on business purchases and investment rather than consumption but also because VATs (GST/HST and QST) continue to impose some taxation on production (e.g. owing to the treatment of the financial sector) and may not necessarily be fully shifted forward, that is, passed through to final consumers (Benedek et al. 2015). ${ }^{14}$ See e.g. the discussion in Bird, Mintz and Wilson (2006). Interesting reviews of this argument in more general terms may be found in Keen and Lockwood (2010) and Alavotunki and Pirttila (2015). Interestingly, the latter paper also emphasizes that - contrary to the views of some (e.g. Emran and Stiglitz 2005) - substituting VATs for other forms of consumption taxes (customs, excises, older forms of sales tax) appears on the whole to have improved rather than worsened the effects of growth on equity.
} 
Interestingly, despite all the fuss in recent years about carbon taxes, perhaps the most striking feature of the changing composition of provincial sales and excise taxes depicted in Figure 3 has been the almost constant slow decline of the importance of gasoline taxes from 6 per cent of total provincial taxes in 1981 to less than 4 per cent in 2014. Although the importance of provincial tobacco taxes has risen a bit over time, particularly in the last few years, perhaps reflecting greater acceptance of such taxes for public health reasons- despite their proven regressivity ${ }^{15}$ - the opposite has occurred with liquor taxes (including markups) which have declined sharply over the years from to the point where they now provide only about 3 per cent of provincial revenues. In contrast, provincial sales tax revenues grew more or less proportionally with GDP over the 1991-2014 period (with an income-elasticity of 1.03), performing significantly better in this respect than federal sales tax revenues, which (with an income-elasticity of only 0.78 ) failed to keep pace with income growth, largely of course as a result of the rate cuts in 2006 and $2008 .{ }^{16}$

Since the GST was introduced in 1991, as Table 2 shows the share of provincial taxes in total taxes has increased substantially. As a share of GDP, total federal taxes first rose from 15.6 per cent of GDP in 1981 to 16.6 per cent of GDP in 1991, before declining to only 13.0 per cent in 2014. Provincial taxes, however, rose from 10.3 per cent of GDP in 1981 to 13.2 per cent in 1991 and declined much less - to 12.2 per cent of GDP - by 2014. Although the share of total federal and provincial taxes provided by sales taxes remained almost constant over this period, as a share of GDP total sales tax revenues actually fell from 5.2 per cent of GDP in 1991, the year the GST was introduced, to only 4.4 per cent in 2014. As noted earlier, the GST and its provincial companions have not proved to be much of a 'money machine' for Canadian government. Indeed, as Figure 2 shows, sales tax revenue increased far more rapidly at the federal level during the 1980s before the GST was introduced than after 1991, even before the rate cuts. After those cuts, the federal GST in 2014 accounted for almost the same share of federal revenue as the antique manufacturer's excise tax had generated 35 years earlier. The story at the provincial level is not that different. Provincial sales taxes increased slightly from 20.3 per cent of provincial taxes (2.6 per cent of GDP) in 1991 to 21.0 per cent (2.9 per cent of GDP) in 2014 but it is not clear how much, if any, of this improved revenue performance is attributable to the fact that a number of provinces changed from an RST to a VAT during this period.

Summing up, the real story of value-added taxation in Canada is not that the introduction of the GST signified a major change in the composition of the tax system. ${ }^{17}$ It did not: the extent to which Canadian taxes fell on consumption rather than income was not markedly changed. The main result of this major tax policy innovation was instead to change Canada's consumption taxes from a motley collection of levies and duties on specific products (excises and customs duties) and poorly structured single-stage sales taxes imposed to a significant extent on production rather than consumption - thus

\footnotetext{
${ }^{15}$ For a recent Canadian empirical study reinforcing this conclusion, see Gospodinov and Irvine (2007).

${ }^{16}$ The elasticities reported are simple arc elasticities for the period. 1991 is used as a starting point simply because it was the first year the GST was imposed.

${ }^{17}$ As Keen and Lockwood (2010) show, the story in most developed countries is much the same. Despite the concern by many in Europe and elsewhere about the so-called 'VAT gap' reflecting excessive evasion, it appears that the principal explanation lies in remediable administrative failures and not in any structural defect of the tax (Cnossen 2010). Similarly, although In some low-income countries where the VAT was introduced primarily to offset revenue losses as a result of tariff cuts required under the WTO agreements, it appears to have failed to deliver adequate compensatory revenue (Baunsgaard and Keen 2010), the primary cause appears to be less inherent problems with VAT than the administrative problems that plague such countries (Bird and Gendron 2007).
} 
imposing significant burdens on investment and growth ${ }^{18}$-- to a more broad-based sales tax that falls primarily on consumption. Canadians do not pay much if any more in taxes on their consumption than they did 25 years ago. But because the taxes they now pay create fewer barriers to investment and growth than those they replaced, they are likely as a whole better off than they were before setting off down the road to VAT, although the GST and its companions are of course far from perfect. ${ }^{19}$

Both federal and provincial governments now face increasingly difficult budgetary prospects. While most attention is understandably being paid to adjustments on the expenditure side, with growth and productivity being apparently stalled it may perhaps be time again to consider shifting the tax mix in the direction of more reliance on the consumption taxes that, as mentioned earlier, seem to be more conducive to innovation and growth. As mentioned earlier, one important reason this possibility does not seem to have been seriously considered in recent discussions is that consumption taxes are considered to be undesirably regressive, and more regressive taxes seem the last thing the country needs given the recent level of concern with growing inequality. ${ }^{20}$ The discussion in the next section of the incidence of the sales tax thus seems particularly timely.

\section{Sales and excise tax progressivity: New estimates for Canada}

Since there have been few applied studies of tax incidence for Canada, the presumed regressivity of sales taxes might be regarded as being of faith as much as fact. While there was much discussion of the distributional effects of the 1991 GST reform, these were largely based on ex ante simulations rather ex post data. ${ }^{21}$ Because sales taxes exempt savings and savings increase sharply with household income sales tax paid are typically a decreasing percentage of annual incomes, so that sales taxes are inevitably measured as regressive when tax payments and incomes are viewed at a single point in time. The difficult questions relate to changes occurring over the taxpayer's lifetime. While income saved is not subject to sales taxation in the short run, much of what is saved will be consumed and subject to sales taxation later in life; how should these expected future taxes be treated in the analysis? Furthermore, if tax liabilities are to be evaluated on a lifetime basis, then what is the correct measure of ability to pay against which tax liabilities should be judged? These thorny issues -- the appropriate time period over which to make the comparison and the appropriate treatment of saving - need to be considered carefully in determining the progressivity or regressivity of sales and excise taxes. Nevertheless, the lifetime incidence question has been largely ignored in applied studies of sales tax incidence for

\footnotetext{
${ }^{18}$ As noted long ago by Kuo, McGirr and Poddar (1988) and demonstrated for provincial VATs in Canada by Smart and Bird (2009a).

${ }^{19}$ See the discussion of the current state of the federal GST in Mintz and Richardson (2014).

${ }^{20}$ For our own recent contributions to this discussion, see Milligan and Smart (2015) and Bird and Zolt (2015).

${ }^{21}$ See e.g. Grady (1990) for an early study. Kesselman (1994) also presented simulated GST taxes paid at various income levels, based on data from the Social Policy Simulation Model. Curtis and Kingston-Riechers (2010) estimated tax burdens using data from the Family Expenditure Survey (the precursor to the Survey of Household Spending data used in this paper), but the focus of their work is on differences between the GST and the federal Manufacturers' Sales Tax that it replaced.
} 
Canada. ${ }^{22}$ In this section, we present new estimates of sales tax incidence using current data, and we delve in detail into the issue of annual versus lifetime tax incidence.

\subsection{Data and methods}

To estimate the incidence of sales and excise taxes, we require data on tax rates applied to individual commodity purchases, as well as on the expenditure patterns and incomes of Canadian households. Our commodity tax rates are derived from data in the COMTAX component of Statistics Canada's Social Policy Simulation Model (SPSM), with certain adjustments detailed below. ${ }^{23}$ COMTAX estimates the statutory tax rates for indirect (sales and excise) taxes on all intermediate inputs as well as final demand goods in an Input-Output model of the Canadian economy, and computes the resulting change in consumer prices for each commodity assuming full forward shifting of production and final demand taxes to domestic consumer prices. ${ }^{24}$ While this extreme shifting assumption is likely wrong in some important cases, the notion that indirect taxes are shifted onto domestic consumers is standard and probably more correct than any other incidence assumption that might be made operational in a model like ours.

The extent to which indirect taxes are shifted forward to consumers or backward to labour, capital, and other factors of production depends on the extent to which they affect domestic production costs as well as the price of imported substitutes for domestic production. The forward shifting assumption seems generally appropriate for the GST and HST, which are destination-basis value added taxes (with exports and most production inputs including capital goods being zero-rated and imports are fully taxable). It is also likely correct for tobacco and alcohol excise taxes, which are almost entirely taxes on domestic final demand. For taxes on motive fuel as well as the traditional retail sales taxes still operated in three provinces, however, a substantial fraction of tax revenues is derived from taxing business inputs, with the extent to which such taxes are shifted forward to consumers or backward to producers being unclear. ${ }^{25} \mathrm{~A}$ recent IMF study stresses that even VATs like the GST are not always fully shifted forward to consumers in part because of the treatment of the financial sector. ${ }^{26}$ However, in an earlier study of the move from RST to HST in three provinces in 1997 we found evidence consistent with the hypothesis that even input sales taxes were largely shifted forward. ${ }^{27}$ While recognizing that the results are unlikely to be entirely accurate and that more work can usefully be done on this question, on the whole it seems sensible simply to assume full forward shifting for all the taxes studied here.

We apply the 2009 tax rates calculated from the COMTAX data to the household expenditure data from the 2009 Public Use Microdata File of the Survey of Household Spending. ${ }^{28}$ For each household in the 2009 SHS, we estimate sales and excise taxes paid by multiplying the COMTAX tax rate

\footnotetext{
22 The classic study by Davies, St-Hilaire, and Whalley (1984) examines the lifetime incidence question in detail, but using a different method than ours and for a much older version of Canada's tax system that notably excludes the GST. Kesselman and Cheung (2004) briefly present lifetime incidence calculations for all Canadian taxes, including indirect taxes, but provide little detail or context for the estimates.

${ }^{23}$ See Statistics Canada (2009a) for an overview.

${ }^{24}$ In contrast, direct (income) taxes are assumed to be fully shifted backward to the relevant factors of production.

${ }^{25}$ Vermaeten, Gillespie and Vermaeten (1994), for example, assumed that sales taxes on business inputs are fully shifted backward to labour, which seems perhaps extreme.

${ }^{26}$ Benedek et al. (2015)

27 Smart and Bird (2009b).

${ }^{28}$ See Statistics Canada (2009b).
} 
by the corresponding expenditure category in the SHS, summing across all expenditure categories to arrive at total tax paid. We then compute effective tax rates (ETRs) for the key federal and provincial taxes by dividing estimated tax paid by the relevant proxy for the tax base - the choice of which we examine in detail below. Our model is thus a standard fiscal incidence model of the type surveyed by Kesselman and Cheung (2004). We make no attempt to adjust our estimates to reflect any substitution possibilities facing households given the changes in relative consumer prices induced by the tax system. ${ }^{29}$ To analyze the progressive or regressive effects of the tax system, we report the distribution of these effective tax rates as well as some summary measures of tax progressivity.

\subsection{Results}

Table 3 shows our estimated effective tax rates for the broad expenditure categories in the Survey of Household Spending, which are the key inputs into our analysis. ${ }^{30}$ The tax rates are presented separately for the general sales taxes (federal and provincial), and other federal and provincial levies classified as sales and excise taxes such as federal excise taxes and duties (mainly on gasoline and liquor), customs import duties, provincial gasoline and carbon taxes, provincial liquor taxes and profits from liquor commissions, and a few other minor taxes.

The lowest effective tax rates (ETRs) in Table 3 are those on Food (which presumably mainly reflects sales taxes on restaurant food), and on Shelter. The latter, essentially our estimate of taxes on newly built housing under the GST and HST, is discussed further below. Most other categories of consumer expenditure, including Household operation and Furnishings, Clothing, Health care, Recreation, and Miscellaneous expenditures (which are mainly financial services) face tax rates close to the overall average, with ETRs that largely reflect the application of the GST and HST/RST and the differing mix of taxable and exempt treatment applying to suppliers in these sectors. ${ }^{31}$ The highest tax rates are applied to the standard "excisables" of fuel, tobacco, and alcohol. More detailed tax data (not reported in Table 3) show that taxes comprised 28.4 per cent of the consumer price of gasoline and motive fuels, 56.1 per cent for tobacco, and 49.9 per cent for alcoholic beverages. The last figure reflects our treatment of provincial liquor commission profits as taxes on consumers. Presumably these profits reflect in part the cost of capital invested in these enterprises which, if the sector were privatized, would be included in the producer price of the commodities rather than the tax rate. Since we treat all of the profits as taxes, the estimates of regressivity reported here are perhaps a bit higher than they should be.

We made some adjustments to the data to deal with underreporting of certain taxes in COMTAX, and underreporting of certain expenditures in the SHS, which is a recall survey of consumer expenditures with certain persistent anomalies. Specifically, expenditures on certain consumer durable and health care categories were rescaled in order better to match aggregate personal consumption in the national accounts, using procedures described in Statistics Canada (2009a). Tobacco and alcohol

\footnotetext{
${ }^{29}$ An alternative approach, pursued for example by Curtis and Kingston-Reichers (2010), is to estimate demand functions for all tax commodities, and then compute the cost of taxes to a household as measure by equivalent variation for the tax system rather than its estimated tax payments. However, the Canadian sales tax system is fairly close to uniform, except for certain commodities for which substitution possibilities are small, so the difference between equivalent variations and estimated tax payments is small in any case.

${ }^{30}$ The effective tax rate in the table is measured as a percentage of the tax-inclusive sales values. For example, the 5 per cent GST rate is equivalent to 4.76 per cent tax-inclusive rate, and so on.

${ }^{31}$ For a full discussion of GST and HST tax expenditures, see Smart (2012).
} 
expenditures also appear to be underreported in the SHS, as in most household-level surveys. Given the importance of these commodities to overall tax liabilities, we scaled up individual expenditures in these categories so that the estimated total federal tax paid in our data matches the corresponding estimates in the National Accounts of federal tobacco and alcohol tax revenue received in 2009. This approach in effect assumes that each household's true expenditures are proportional to their reported expenditures. $^{32}$

COMTAX sales tax rates exclude taxes levied on purchases of newly built housing under the GST and HST. It is difficult to deal with these important taxes, because they are levied on the purchase of an asset instead of a flow of consumption services. We assume that these taxes fall on consumers in proportion to the flow of housing services they receive according to the SHS data. We therefore scale up the shelter tax rates in the COMTAX data to match control totals for total GST and HST from housing as reported in the Input-Output tables. In effect, this is a steady state model of tax incidence, with taxes on new-built houses constituting a "pre-payment" of taxes for the flow of future services to owner occupied housing by being capitalized into the purchase price. Other assumptions may of course be made about the incidence of housing taxes. For example, Smart (2011) argues that taxing new houses at first sale but exempting resale houses creates capital gains on the existing housing stock at the time the tax is introduced, with the result that there were, in effect, transfers from young consumers (who by definition tend to be "net short" in housing) to existing homeowners at the time of the reform. Unfortunately, SHS data do not allow us to estimate the distribution of GST/HST housing taxes under this alternative incidence model.

\subsection{Results}

The procedures just described yield an estimate of sales taxes paid for each household in the SHS, which we convert to an overall effective tax rate (ETR) by dividing estimated tax payments by one of several possible measures of the appropriate tax base. Table 4 reports the average of these effective rates for vingtiles (twentieth parts) of the distribution of adult-equivalent household income. ${ }^{33}$ The first column of the table uses household total income as reported in the SHS as the tax base (i.e. the denominator in the effective tax rate calculation). Unsurprisingly, and consistently with normal expectations, this approach suggests that sales and excise taxes are quite regressive. The average ETR is 23.6 per cent of income for the poorest 5 per cent of the sample, declines sharply to 11.7 per cent in the next vingtile, and then continues to decline fairly steadily with income to only about 5 per cent for the highest income groups.

As has long been understood, however, income-based ETRs tend to exaggerate the regressivity of consumption taxes when considered over even a slightly longer period, owing to transitory and unpredictable variation in annual income, and more so over a lifetime, owing to longer-run predictable changes in income over the life cycle. Consumption tends to be less volatile than income in the short-

\footnotetext{
32 To avoid introducing new biases into the data, when estimated household tax payments were adjusted in these ways we nevertheless calculated effective tax rates using the unadjusted household income and aggregate consumption measures from the SHS data as the base. See the discussion of effective tax rates below.

${ }^{33}$ To account for differences in family type, we rank households throughout by adult-equivalent income, defined as household total income divided by the square root of family size. Using other equivalence scales, such as that employed for Statistics Canada's Low Income Measure, or the number of adult household members, gives very similar results.
} 
run, as many households can and do use saving and other financial resources to smooth consumption during temporary income changes. In the bottom vingtile of household income, where average total income is just $\$ 9,022$ per adult equivalent compared to total consumption of $\$ 15,221$, such offsetting effects are especially evident, as shown in Table 5. Furthermore, some studies have shown that underreporting leads to biased measures of income in survey data, particularly in the bottom tail of the distribution. ${ }^{34}$

In addition, although we do not report age-related data here, average household saving varies predictably over the life cycle in our data, as mean saving first rises with earnings to late middle age and then declines as household members begin to retire and earnings drop. The fact that household income that is saved is not immediately subject to sales and excise taxes, and savings rise with household income, is another reason that income-based ETRs exhibit regressivity. At the extreme, however, if all commodities were taxed at a uniform rate, all households could borrow and lend at the same interest rates, and all savings were ultimately consumed before death rather than bequeathed, then lifetime present-value sales taxes would be proportional to lifetime present-value income for all households. Although none of these assumptions is completely correct, since much saving is consumed - and hence subject to sales and excise taxes -- later in life, these taxes are clearly far less regressive on a lifetime present-value basis than the annual data would suggest.

The direct approach to dealing with life-cycle issues would be to compute sales tax burdens on a lifetime present-value basis, as a percentage of lifetime human wealth. ${ }^{35}$ However, the necessary longitudinal expenditure survey data simply do not exist for Canada. An alternative approach, proposed by Poterba (1989) and others, is to compute effective tax rates based on annual tax payments as a fraction of current annual consumption. Under the permanent income hypothesis, current consumption is a better measure of lifetime expected wealth, so that consumption-based ETRs serve as a proxy for the lifetime expected redistributive effects of sales taxes. The consumption proxy approach is admittedly imperfect when, for example, households face borrowing constraints or engage in precautionary saving, as they do. ${ }^{36}$ Some consumption might be from inheritance, and some saving might be for bequests, so that present-value incomes and consumption levels are not equal over the life cycle. Moreover, the implications of life cycle patterns in specific expenditures will not be adjusted correctly under this approach. For example, if consumption of tobacco (which is highly taxed) falls as people age and income rises over the life cycle, then the consumption-based ETR will overstate the regressivity of consumption taxes because it fails to capture pure age-related changes in future taxes that are correlated with current income. Despite such caveats, computing consumption-based ETRs remains a simple but powerful way to estimate a reasonable proxy for the lifetime incidence of sales taxes.

\footnotetext{
${ }^{34}$ For evidence on this for Canada, see Brzozowski and Crossley (2011), which compares income-based and consumption-based measures of wellbeing more generally.

35 This is the approach taken for example by Lyon and Schwab (1991) for US data. Another approach, used by Davies, St-Hilaire and Whalley (1984), employs cross-section data like ours and simulates lifetime expected income and taxes based on assumptions about the stochastic process for annual income and the stability of expenditure patterns across birth cohorts.

${ }^{36}$ Note, however, that if low-income households face borrowing constraints or engage in precautionary saving that reduce current consumption below permanent income, the consumption-based ETRs shown in Table 4 will tend to overstate regressivity.
} 
Consumption-based ETRs for aggregate sales and excise taxes are presented in the third column of Table 4 , and also graphically in Figure 4. On this basis, effective tax rates are nearly proportional to ability to pay, equalling 10.1 per cent on average in the bottom vingtile of adult-equivalent income and 10.3 per cent in the richest vingtile, with no discernable trends in between. Using the consumption base, then, sales and excise taxes are close to proportional. While the direction of this effect is as expected, the extent of proportionality in the data is perhaps surprising. Many features of the sales and excise tax system are ostensibly designed to reduce the presumed regressive impact of sales taxes - particularly the various exemptions and zero-rating measures in the federal and provincial general sales taxes (Smart 2012). If these non-uniformities in taxation were having the intended effect, then we would expect consumption-based ETRs to rise with income rather than be roughly constant. We return to the reasons for this finding below.

The foregoing comparison of income-based and consumption-based ETRs concentrated on differences in savings rates by income level but of course savings are only part of the difference between income and consumption. As a matter of definition, we may think of income and consumption as being linked in the SHS by the identity

$$
\text { Consumption }=\text { Income }- \text { Net Income Adjustments }- \text { Personal Taxes + Saving }
$$

or, more simply,

$$
\text { Consumption }=\text { Adjusted Disposable Income }+ \text { Saving }
$$

where "Net Income Adjustments" refers to accounting adjustments to income to reflect differences between economic concepts of income and the way in which it is measured in practice in the SHS data. To see the role of these measures, define $t$ as an individual's personal taxes plus net income adjustments as a fraction of income, and $s$ as the savings rate as a fraction of adjusted disposable income. Then it is easy to show that the income-based and consumption based effective tax rate measures shown in Table 4 are related as follows:

$$
E T R I N C=E T R C O N \times(1-t) \times(1-s)
$$

The differences in the patterns of the income-based and consumption-based ETRs observed in Figure 4 thus reflect the pattern of adjusted personal tax rates, of savings rates, or both. We consider each in turn.

Because income tax rates are progressive, 1-t declines with income, leading to greater regressivity under the (pre-tax) income tax base proxy than under any proxy that deducts taxes from the denominator of the ETR calculations. As shown in Table 5, personal taxes are negligible in the bottom quintile (a net refund of $\$ 9$ per adult equivalent family member), rising to about 15 per cent of income for the median household, and 30 per cent of income in the top vingtile of the data. Using Adjusted Disposable Income in place of Income as the base proxy thus deals with an inconsistency in the SHS income accounting methodology. The SHS data provides a measure of "broad income" including major transfers received as part of income (including transfers delivered through the tax system). However, because the fisc mainly operates on low-income families through transfers, and on high-income families through taxes SHS income is "too high" and income-based ETRs "too low" for high-income families relative to low-income families, leading to an exaggerated impression of sales tax regressivity based on 
the broad income base. This is an inconsistency in measurement within the SHS data. Using income net of taxes as the appropriate income base seems more consistent given the data.

We make two additional adjustments to the disposable income data. First, in the SHS data private pension income is counted as part of total income, whereas pension contributions are not included in consumption. Whether such contributions are regarded as saving or a deduction from income is irrelevant to comparison between income and consumption in our data, but it does result in another asymmetry in the treatment of high-income and low-income households because retirement income of the latter group comes disproportionately from government transfers financed in part by personal taxes during their working life. Moreover, as noted by Benjamin and Smart (2012), the SHS approach overstates savings by the elderly, for whom consumption is largely financed out of pension accumulations, because no offsetting adjustment to pension wealth is included in the SHS. For these reasons, it seems preferable to deduct private pension contributions from adjusted disposable income in the data. As shown in Table 5, pension contributions also rise with household income, particularly above median income.

Second, we include net gifts received as disposable income of households. As shown in Table 5, gifts received are a substantial means of financing consumption for the poorest households, and net payments by households in the top vingtiles are also large. (Gifts received include transfers from charities.) It is an open question whether these transfers represent ability to pay taxes in the usual sense or not. Arguably, however, they probably do and so should be included in the base on which ETRs are computed.

To show the importance of these various adjustments, Table 4 also displays ETRs calculated using Adjusted Disposable Income as the base measure, in place of the two conventional alternatives Income (column 1) and consumption (column 3). The difference between columns 2 and 1 of Table 2 is that personal taxes and net income adjustments are excluded from the base, and the difference between columns 3 and 2 is that savings is also excluded from the base. As displayed graphically in Figure 4, adopting the adjusted disposable income base eliminates about half the difference in incomebased and consumption-based ETRs at most income levels. In other words, the treatment of taxes/transfers and the treatment of savings are each about equally important in explaining the difference between income-based and consumption-based ETRs.

A final issue is how to explain the surprising near proportionality of sales and excise taxes under the consumption base. Table 6 presents consumption-based ETRs separately for federal and provincial taxes, and general sales taxes versus excises. ${ }^{37}$ ETRs for the federal GST rise with income due to the exemptions, and are about 20 per cent higher in the top deciles of adult-equivalent income, compared to the bottom deciles. Provincial general sales taxes (the HST in participating provinces, the QST in Quebec, and RSTs in most other provinces) are in contrast roughly proportional to consumption, except at the very bottom of the income distribution. ${ }^{38}$ In contrast, federal excise taxes are mildly regressive, and provincial excise taxes more strongly so, reflecting the fact that standard "excisables," particularly tobacco, comprise larger expenditure shares at lower income levels. Consequently, while our data

\footnotetext{
37 "Excises" here include all indirect taxes levied by federal and provincial governments outside of the general sales $\operatorname{tax}$.

${ }^{38}$ Although this issue needs further examination it seems likely that in part it may reflect differences among provinces in the way in which separate excise taxes are treated in the general sales tax.
} 
suggest that general sales taxes (particularly the GST) are on the whole mildly progressive on a lifetime basis, excise taxes as a whole remain decidedly regressive.

Finally, to help make sense of the many numbers in Table 6, we present in Table 7 an aggregate measure of progressivity for each of the four tax components, using an index of tax progressivity proposed by Blackorby and Donaldson (1984). The Blackorby-Donaldson family of index numbers relates tax progressivity to the change in inequality induced by taxes, relative to what would be achieved with a proportional tax on consumption that yields the same revenue. We report the BlackorbyDonaldson index for various measures of the degree of social aversion to consumption inequality - a higher parameter $e$ indicating greater social preference for redistribution. ${ }^{39}$ Note that, by these measures, a positive (negative) index number indicates a tax system that is more progressive (regressive) than a proportional tax on all consumption goods. The results in Table 7 show a clear pattern that confirms the initial impressions from the distribution of ETRs reported in Table 6. Regardless of inequality aversion, general sales taxes are in fact mildly progressive on a lifetime basis, mainly due to the exclusion of basic foods from the tax bases. In contrast, the table shows that provincial excise taxes are somewhat regressive, due mainly to the high tax rates of tobacco products which constitute about 3.5 per cent of consumption in the bottom decile of the income distribution, compared to less than two per cent at median income. ${ }^{40}$ On balance, total sales and excise taxes are therefore nearly proportional, or slightly regressive at high rates of inequality aversion. But the overall effects are in any case very close to that of a proportional tax system.

Summing up what has been an inevitably rather complex discussion, it is clearly true that, as often assumed in popular discussion, the conventional approach to measuring sales tax redistribution, using income-based ETRs, suggests considerable regressivity in the Canadian system. However, it is well known that this result is strongly influenced by exceptionally high rates at the very bottom of the distribution which not only decline very quickly but both in practice and in principle seem most unlikely to provide an accurate depiction of the distribution of tax burdens over time. A better way to measure sales tax incidence on the whole is to compute consumption-based ETRs. When we do so, we find that although Canada's general sales taxes turn out to be mildly progressive when viewed through this lens, excise taxes are still regressive and the sales and excise tax system on the whole extremely close to a proportional tax on consumption.

\section{Concluding Remarks}

We make four major points in this brief article:

\footnotetext{
${ }^{39}$ For the purposes of computing the tax progressivity index, the index of consumption inequality we adopt is the Atkinson "mean of order e" index, for three different measures of the degree of inequality aversion in society, captured by the parameter e. We set e equal to $0.5,1$, and 2.5 , which are common parameter values used in applied studies of income inequality. In this case, the Blackorby-Donaldson index may be more simply understood as measuring the percentage change in the social welfare function that is induced by the tax system.

${ }^{40}$ Of course, this conclusion about tobacco taxation (and excise taxes in general) is solely about the fiscal calculation reported. As is well known, if the long-term health effects of tobacco consumption are not fully taken into account by consumers, then taxing tobacco might provide sufficiently positive effects on harm reduction to more than offset its fiscal impacts. Similarly, taxes on both alcohol and motor fuels may have some beneficial "corrective" effects on individual behaviour which would need to be taken into account in a more complete analysis of their effects on national welfare.
} 
1. The revenue importance and the burden on taxpayers of Canada's sales and excise taxes have changed surprisingly little over time.

2. However, the composition of sales and excise taxes (understanding the latter term broadly to include all indirect taxes other than general sales taxes) has changed in two major ways: the importance of provincial compared to federal taxes has increased over time, and, more importantly, general sales taxes are now much more important relative to excise taxes.

3. This change in composition suggests that the regressivity of sales and excise taxes has lessened since the introduction of the GST, regardless of how one measures that incidence.

4. Finally, we argue that there is a better case for using consumption than income as a basis for evaluating the progressivity of sales and excise taxes, and that the GST and its companion taxes appear on this measure to be mildly progressive, although the marked regressivity of the remaining excises means that even on this basis the sales and excise system remains mildly regressive.

Obviously, more research on the incidence question is always possible and desirable. However, a final conclusion suggested by this paper is that those concerned with tax regressivity would seem best advised to focus on excise taxes for two reasons. First, what McLure and Thirsk (1978) once called "the inequity of taxing iniquity" continues to be a matter of concern, and, second, the importance of this issue may perhaps increase in the future both as the world moves more to some kind of "carbon pricing" and as a result of the continuing pressure from some quarters to raise "sin taxes" on products such as tobacco and alcohol for health and social reasons. ${ }^{41}$

${ }^{41}$ For a recent examination of some of the latter arguments in a different context, see Bird (2015b). 


\section{References}

Alavuotunki, K. and J. Pirttila (2015) The Consequences of the Value-Added Tax on Inequality in Developing Countries, available at www.wider.unu.edu/sites/default/files/wp2015-111.pdf (accessed February 28, 2016)

Baylor, M. and L. Beausejour (2004) Taxation and Economic Efficiency: Results from a Canadian CGE Model, Department of Finance Working Paper 2004-10, November, available at https://www.researchgate.net/publication/5022172 Taxation and Economic Efficiency Results from a Canadian CGE Model (accessed February 28, 2016)

Baunsgaard, T. and M. Keen (2010) "Tax Revenue and (or?) Trade Liberalization," Journal of Public Economics, 94(9-10): 563-577.

Benedek, D. et al. (2015) Estimating VAT Pass Through, IMF Working Paper WP/15/214, available at www.imf.org/external/pubs/ft/wp/2015/wp15214.pdf (accessed February 28, 2016)

Benjamin, D. and M. Smart (2012) Savings Trends in Canada, Working paper, University of Toronto.

Bird, R.M. (2010) “Visibility and Accountability-- Is Tax-Inclusive Pricing a Good Thing?” Canadian Tax Journal, 58 (1): 63-76.

Bird, R.M. (2015a) "Below the Salt: Decentralizing Value-Added Taxes," in Ehtisham Ahmad and Georgio Brosio, eds., Handbook of Multilateral Finance (Cheltenham UK: Edward Elgar), pp. 291-333.

Bird, R.M. (2015b) Tobacco and Alcohol Excise Taxes for Improving Public Health and Revenue Outcomes: Marrying Sin and Virtue? Policy Research Working Paper 7500, World Bank, November.

Bird, R.M. and P.-P. Gendron (2007) The VAT in Developing and Transitional Countries (Cambridge University Press).

Bird, R.M., J.M. Mintz and T.A.Wilson (2006) "Coordinating Federal and Provincial Sales Taxes: Lessons from the Canadian Experience," National Tax Journal, 49 (4): 889-903.

Bird, R.M. and E. Zolt (2015) "Taxes, Spending and Inequality in Canada and the United States: Two Stories or One?" Osgoode Hall Law Journal, 52 (2): 401-427.

Blackorby, C. and D. Donaldson (1978) "Measures of Relative Inequality and Their Meaning in Terms of Social Welfare," Journal of Economic Theory, 18 (1): 59-80.

Brzozowski, M. and T.F. Crossley (2011) "Viewpoint: Measuring the well-being of the poor with income or consumption: a Canadian perspective" Canadian Journal of Economics, 44 (1): 88-106

Cnossen, S. (2010) "Commentary," in Adam, S. et al., eds., Dimensions of Tax Design: The Mirrlees Review (Oxford: Oxford University Press), pp. 370-386. 
Curtis, L., and J. Kingston-Riechers (2010) "Implications of the Introduction of the Goods and Services Tax for Families in Canada," Canadian Tax Journal 36 (4): 503-520.

Davies, J., F. St-Hilaire and J. Whalley (1984) "Some Calculations of Lifetime Tax Incidence," American Economic Review, 74 (4): pp. 633-649

Emran, M. S. and J.E. Stiglitz (2005) “On Selective Indirect Tax Reform in Developing Countries," Journal of Public Economics, 89: 599-623.

Gospodinov, N. and I. Irvine (2007) Tobacco Taxes and Regressivity, Concordia University, January, available at https://www.researchgate.net/publication/23672483 Tobacco taxes and regressivity (accessed February 28, 2016)

Grady, P. (1990) "An Analysis of the Distributional Impact of the Goods and Services Tax," Canadian Tax Journal, 38 (3): 632-643.

Johansson, A. et al. (2008) Taxation and Economic Growth, OECD Economics Department Working Papers No. 620, available at www.oecd.org/tax/tax-policy/41000592.pdf (accessed February 28, 2016)

Keen, M., and B. Lockwood (2010). 'The Value Added Tax: Its Causes and Consequences'. Journal of Development Economics, 92 (2010): 138-51.

Kesselman, J. R. (1994) "Assessing a Direct Consumption Tax To Replace the GST," Canadian Tax Journal 42 (3): 709-803.

Kesselman, J.R. and R. Cheung (2004) "Tax Incidence, Progressivity, and Inequality in Canada," Canadian Tax Journal, 52 (3): 709-789.

Kesselman, J.R. and P. Spiro (2014) "Challenges in Shifting Canadian Taxation Toward Consumption," Canadian Tax Journal, 62 (1): 1-41.

Kuo, C-Y, T. McGirr, and S. Poddar (1988) "Measuring the Non-neutralities of Sales and Excise Tax in Canada," Canadian Tax Journal, 36: 655-70.

Lyon, A. and R. Schwab (1991) Consumption Taxes in a Life-Cycle Framework: Are Sin Taxes Regressive? NBER Working Papers 3932, National Bureau of Economic Research, Inc.

McKenzie, K. (2015) “The Corporate Income Tax in Canada: Past, Present and Future," Canadian Tax Journal, 63 (4): 1011-1026.

McLure, C.E. and W.R. Thirsk (1978) "The Inequity of Taxing Iniquity: A Plea for Reduced Sumptuary Taxation in Developing Countries," Economic Development and Cultural Change, 26(3): 497-503.

Milligan, K. (2014) "The Growth of Government in Canada: A $21^{\text {st }}$ Century Perspective," Canadian Tax Journal, 63 (3): 739-750.

Milligan, K. and M. Smart (2015) "Provincial Taxation of High Incomes," Canadian Journal of Economics, 48(2), 655-681. 
Mintz, J.M. and S.R. Richardson, eds. (2014) After Twenty Years: The Future of the Goods and Services Tax (Toronto: Canadian Tax Foundation).

Perry, J.H. (1989) A Fiscal History of Canada - The Postwar Years (Toronto: Canadian Tax Foundation).

Poterba, J. M., 1989, "Lifetime Incidence and the Distributional Burden of Excise Taxes," American Economic Review, 79 ( 2): 325-330.

Richards, J. (2012) “British Columbia's Unharmonized Referendum - The Problem with Plebiscitary Democracy," Canadian Tax Journal, 60 (1): 103-112.

Robertson, D.D. (2012) "Comparing the Introduction of the HST in British Columbia and Ontario Lessons from the Political Trenches," Canadian Tax Journal, 60 (1): 113-122.

Smart, M. (2011) Why do VATs Tax Housing so Little? Working paper, University of Toronto.

Smart, M. (2012) Departures from Neutrality in Canada's Goods and Services Tax, SPP Research Papers Vol. 5, No. 5, School of Public Policy, University of Calgary.

Smart, M. and R. Bird (2009a) "The Impact on Investment of Replacing a Retail Sales Tax by a ValueAdded Tax: Evidence from Canadian Experience," National Tax Journal, 62 (4): 591-609.

Smart, M. and R. Bird (2009b) "The Economic Incidence of Replacing a Retail Sales Tax with a ValueAdded Tax: Evidence from Canadian Experience," Canadian Public Policy, 35(1): 85-97.

Statistics Canada (2009a) SPSD/M Commodity Tax User's Guide.

Statistics Canada (2009b) User Guide for the Survey of Household Spending.

Treff, K.and D. Ort (2011) Finances of the Nation 2011 (Toronto: Canadian Tax Foundation). Vermaeten, F., W.I.Gillespie, and A. Vermaeten (1994) "Tax Incidence in Canada," Canadian Tax Journal, 42 (2): 348-416. 
Table 1.Sales Tax Rates in Canada

\begin{tabular}{|c|c|c|c|c|c|}
\hline \multirow[t]{3}{*}{ Jurisdiction } & \multirow{3}{*}{$\begin{array}{l}\text { Name of } \\
\text { Tax }\end{array}$} & \multirow{3}{*}{$\begin{array}{l}\text { Type of } \\
\text { Tax }\end{array}$} & Rate & Initial Rate (\%) & \multirow[t]{3}{*}{ Notes on Major Rate Changes } \\
\hline & & & 2015 & $\begin{array}{l}\text { (Year of } \\
\text { Introduction) }\end{array}$ & \\
\hline & & & (\%) & & \\
\hline Canada & GST & VAT & 5 & 7 (1991) & $\begin{array}{l}\text { Rate lowered to } 6 \% \text { in } 2006 \text { and } 5 \% \text { in } \\
2008\end{array}$ \\
\hline $\begin{array}{l}\text { Newfoundland and } \\
\text { Labrador }\end{array}$ & HST & VAT & 8 & $8(1996)$ & $\begin{array}{l}\text { HST replaced } 12 \% \text { RST (introduced in } \\
1950 \text { at } 2 \%, \text { increased to } 3 \% \text { in } 1951 \text {, } \\
5 \% \text { by } 1961,6 \% \text { by } 1966,7 \% \text { by } 1971 \text {, } \\
10 \% \text { by } 1976,11 \% \text { in } 1979 \text {, and } 125 \text { in } \\
1983 \text { ); PST rate scheduled to increase } \\
\text { to } 10 \% \text { in } 2016\end{array}$ \\
\hline Nova Scotia & HST & VAT & 10 & 8 (1996) & $\begin{array}{l}\text { HST replaced } 10 \% \text { RST (introduced in } \\
1959 \text { at } 2 \%, \text { increased to } 5 \% \text { by } 1961 \text {, } \\
7 \% \text { by } 1971,8 \% \text { by } 1976 \text {, and } 10 \% \text { in } \\
1982 \text { ); rate increased to } 10 \% \text { in } 2010\end{array}$ \\
\hline New Brunswick & HST & VAT & 8 & 8 (1996) & $\begin{array}{l}\text { HST replaced } 10 \% \text { RST (introduced in } \\
1950 \text { at } 4 \% \text {, reduced to } 3 \% \text { by } 1961 \text {, } \\
\text { then increased to } 6 \% \text { by } 1966 \text {, and } \\
11 \% \text { to } 1971 \text { before reduced again to } \\
8 \% \text { by } 1976 \text {, then increased to } 10 \% \text { in } \\
1983 \text { and } 11 \% \text { in } 1985 \text { ) }\end{array}$ \\
\hline $\begin{array}{l}\text { Prince Edward } \\
\text { Island }\end{array}$ & HST & VAT & 9 & $9(2013)$ & $\begin{array}{l}\text { HST replaced } 10 \% \text { RST (introduced in } \\
1960 \text { at } 2 \% \text {, increased to } 4 \% \text { by } 1961 \text {, } \\
5 \% \text { by } 1966,8 \% \text { by } 1971 \text {, then to } 9 \% \\
\text { in } 1980 \text { and } 10 \% \text { in } 1981 \text { ) }\end{array}$ \\
\hline Quebec & QST (TVQ) & VAT & 9.975 & 8 (1991) & $\begin{array}{l}\text { TVQ replaced } 8 \% \text { RST (introduced in } \\
1940 \text { at } 2 \%, \text { but increased to } 8 \% \text { by } \\
1966, \text { then } 9 \% \text { in } 1982 \text { ); base now } \\
\text { almost same as GST; until } 2013 \\
\text { included GST in base. }\end{array}$ \\
\hline Ontario & HST & VAT & 8 & $8(2010)$ & $\begin{array}{l}\text { HST replaced } 8 \% \text { RST (introduced in } \\
1961 \text { at } 3 \% \text {, with increases to } 5 \% \text { by } \\
1966,7 \% \text { by } 1976 \text {, and a final } \\
\text { increase to } 85 \text { in } 1988 \text { ) }\end{array}$ \\
\hline Manitoba & PST & RST & 8 & $5(1967)$ & $\begin{array}{l}\text { Increased to } 6 \% \text { in } 1983 \text {, and } 7 \% \text { in } \\
1987\end{array}$ \\
\hline Saskatchewan & PST & RST & 5 & 2 (1937) & $\begin{array}{l}\text { Increased to } 4 \% \text { by } 1951,5 \% \text { by } 1961 \text {, } \\
\text { then to } 7 \% \text { in } 1987 \text { before being } \\
\text { reduced to } 5 \% \text { in } 2007 \text {. }\end{array}$ \\
\hline Alberta & None & & & & $\begin{array}{l}\text { Introduced RST at } 2 \% \text { in 1936; } \\
\text { abolished in } 1937\end{array}$ \\
\hline British Columbia & PST & RST & 7 & $2(1948)$ & $\begin{array}{l}\text { RST rate was raised to } 3 \% \text { by } 1951 \text {, } \\
5 \% \text { by } 1955 \text {, and } 7 \% \text { by } 1976 \text {, then } \\
\text { reduced to } 4 \% \text { by } 1979 \text {, and raised } \\
\text { again to } 6 \% \text { in } 1981 \text { and } 7 \% \text { in } 1983 \text {, } \\
\text { then cut to } 6 \% \text { in } 1987 . \text { In } 2010, \\
\text { when the RST rate was again } 7 \% \text { it } \\
\text { was replaced by a } 7 \% \text { HST, then a } 7 \% \\
\text { RST in } 2013 \text {. }\end{array}$ \\
\hline
\end{tabular}

Note: Provincial rate shown for HST provinces in 2015 is for provincial portion of HST only; the tax consumers see is of course the full HST rate, consisting of the provincial sales tax plus the 5 per cent federal GST.

Sources: Historical information from Perry (1989), Table 16.14; current information from http://www.taxtips.ca/salestaxes/sales-tax-rates2015.htm 
Table 2 - Trends in Sales and Excise Taxes, 1981-2014

\begin{tabular}{|c|c|c|c|c|c|}
\hline & \multirow{2}{*}{1981} & \multirow{2}{*}{1991} & \multirow{2}{*}{2014} & \multicolumn{2}{|c|}{ Percent change } \\
\hline & & & & 1991-2014 & 1981-2014 \\
\hline Federal sales and excise taxes & \multicolumn{3}{|c|}{ (\% of total federal taxes) } & & \\
\hline General sales tax & 11.0 & 15.0 & 14.1 & $-6.0 \%$ & $28.2 \%$ \\
\hline Other sales and excise taxes & 8.9 & 8.0 & 6.0 & $-25.0 \%$ & $-32.6 \%$ \\
\hline Total federal & 19.9 & 23.0 & 20.1 & $-12.6 \%$ & $1.0 \%$ \\
\hline Provincial sales and excise taxes & \multicolumn{3}{|c|}{ (\% of total provincial taxes) } & & \\
\hline General sales tax & 19.2 & 20.3 & 21.0 & $3.4 \%$ & $9.4 \%$ \\
\hline Other sales and excise taxes & 13.3 & 11.5 & 10.3 & $-10.4 \%$ & $-22.6 \%$ \\
\hline Total provincial & 32.5 & 31.8 & 31.3 & $-1.6 \%$ & $-3.7 \%$ \\
\hline Total sales and excise taxes & \multicolumn{3}{|c|}{ (\% of total taxes) } & & \\
\hline General sales tax & 14.2 & 17.4 & 17.5 & $0.6 \%$ & $23.2 \%$ \\
\hline Other sales and excise taxes & 10.7 & 9.5 & 8.0 & $-15.8 \%$ & $-25.2 \%$ \\
\hline Total & 24.9 & 26.9 & 25.5 & $-5.2 \%$ & $2.4 \%$ \\
\hline \multicolumn{6}{|l|}{ Memo items: } \\
\hline General sales taxes as \% of household consumption & 7.1 & 9.2 & 8.1 & $-12.0 \%$ & $14.1 \%$ \\
\hline Total sales and excise taxes as $\%$ of household consumption & 12.6 & 14.3 & 11.8 & $-17.5 \%$ & $-6.3 \%$ \\
\hline Total taxes as \% GDP & 25.9 & 29.8 & 25.2 & $-15.4 \%$ & $-2.7 \%$ \\
\hline Federal taxes as \% of total taxes & 60.2 & 55.7 & 51.6 & $-7.4 \%$ & $-14.3 \%$ \\
\hline
\end{tabular}

Notes: This table is based on national accounts data. Federal sales and excise taxes include manufacturers' sales tax until 1991 when it was replaced by the GST, as well as customs duties, excise duties, and taxes on gasoline and motive fuel; provincial sales and excise taxes include sales taxes (retail sales taxes, HST, and QST, as appropriate) as well as taxes on gasoline, tobacco, and liquor (including markups) as well as taxes included as other sales taxes. Household consumption is as defined in national accounts.

Sources: Calculated from data in Statistics Canada, Tables 380-0080 and 380-0081. 
Table 3 - 2009 sales and excise tax rates, by commodity group

\begin{tabular}{|c|c|c|c|c|c|}
\hline & \multicolumn{2}{|c|}{ Federal } & \multicolumn{2}{c|}{ Provincial } & $\begin{array}{c}\text { Combine } \\
\mathbf{d}\end{array}$ \\
\hline Expenditure Category & GST & Other & HST/RST & Other & Total \\
\hline Food & 1.6 & 0.4 & 2.2 & 0.3 & 4.4 \\
\hline Shelter & 2.7 & 0.1 & 2.0 & 0.2 & 2.6 \\
\hline Household operation & 4.0 & 0.2 & 4.8 & 0.2 & 9.2 \\
\hline Household furnishings and equipment & 5.4 & 1.2 & 7.5 & 0.3 & 14.4 \\
\hline Clothing & 4.5 & 3.1 & 5.6 & 0.2 & 13.5 \\
\hline Transportation & 4.3 & 2.7 & 5.1 & 3.1 & 15.3 \\
\hline Health care & 3.0 & 0.3 & 3.3 & 0.3 & 7.0 \\
\hline Recreation, Education, and reading \\
materials & 3.3 & 0.3 & 3.9 & 0.3 & 7.8 \\
\hline Tobacco and alcohol & & & & & \\
\hline Miscellaneous expenditures & 5.2 & 11.3 & 5.4 & 31.5 & 52.4 \\
\hline
\end{tabular}

Notes: Authors' estimates, based on 2009 COMTAX and Survey of Household Spending data. 
Table 4 - Effective tax rates by vingtiles of adult-equivalent total income, under alternative proxies for the tax base

\begin{tabular}{lcccc}
$\begin{array}{l}\text { Vingtile of } \\
\text { adult-equivalent } \\
\text { total income: }\end{array}$ & $\begin{array}{c}\text { Total } \\
\text { Income }\end{array}$ & $\begin{array}{c}\text { Pdjusted Disposable } \\
\text { Income }\end{array}$ & $\begin{array}{c}\text { Total } \\
\text { Consumption }\end{array}$ \\
\cline { 2 - 5 } & 1 & 0.236 & 0.171 & 0.101 \\
& 2 & 0.117 & 0.128 & 0.093 \\
& 3 & 0.105 & 0.109 & 0.092 \\
& 4 & 0.101 & 0.109 & 0.093 \\
& 5 & 0.106 & 0.132 & 0.106 \\
& 6 & 0.097 & 0.113 & 0.101 \\
& 7 & 0.094 & 0.110 & 0.105 \\
& 8 & 0.091 & 0.125 & 0.108 \\
& 9 & 0.083 & 0.104 & 0.102 \\
& 10 & 0.088 & 0.109 & 0.109 \\
& 11 & 0.081 & 0.106 & 0.106 \\
& 12 & 0.081 & 0.106 & 0.109 \\
& 13 & 0.079 & 0.101 & 0.106 \\
& 14 & 0.073 & 0.102 & 0.104 \\
& 15 & 0.070 & 0.092 & 0.106 \\
& 16 & 0.066 & 0.092 & 0.104 \\
& 17 & 0.064 & 0.092 & 0.105 \\
18 & 0.061 & 0.088 & 0.102 \\
19 & 0.057 & 0.085 & 0.103 \\
20 & 0.047 & 0.080 & 0.103 \\
\hline & 0.090 & 0.108 & 0.103 \\
& & &
\end{tabular}

Source: Authors' calculations, based on 2009 COMTAX and SHS data. See text for details. 
Table 5 - The distribution of components of household consumption

\begin{tabular}{|c|c|c|c|c|c|}
\hline \multirow{2}{*}{$\begin{array}{c}\text { Vingtile of } \\
\text { adult-equivalent }\end{array}$} & \multicolumn{5}{|c|}{ Adult-equivalent levels of: } \\
\hline & Personal & Net Gifts & Pension & & Total \\
\hline total income: & Taxes & Received & Contributions & Savings & Consumption \\
\hline 1 & -9 & 3,295 & 172 & $-3,067$ & 15,221 \\
\hline 2 & 222 & 224 & 323 & $-3,588$ & 17,261 \\
\hline 3 & 356 & 1,254 & 425 & $-1,674$ & 19,122 \\
\hline 4 & 563 & 47 & 493 & $-2,272$ & 20,978 \\
\hline 5 & 1,625 & 807 & 825 & $-1,564$ & 22,692 \\
\hline 6 & 2,212 & 282 & 1,070 & $-1,683$ & 24,467 \\
\hline 7 & 2,941 & -58 & 1,334 & -847 & 25,476 \\
\hline 8 & 3,948 & -500 & 1,630 & -575 & 26,608 \\
\hline 9 & 4,720 & -350 & 1,909 & 189 & 27,979 \\
\hline 10 & 5,246 & 261 & 2,097 & 835 & 30,428 \\
\hline 11 & 6,290 & 207 & 2,514 & 1,733 & 31,386 \\
\hline 12 & 7,164 & -286 & 2,428 & 1,453 & 33,936 \\
\hline 13 & 7,659 & 666 & 3,111 & 2,846 & 36,124 \\
\hline 14 & 9,812 & -290 & 5,319 & 501 & 37,333 \\
\hline 15 & 10,711 & -142 & 4,242 & 4,618 & 38,455 \\
\hline 16 & 12,796 & -461 & 3,977 & 6,902 & 40,034 \\
\hline 17 & 15,629 & -177 & 4,318 & 8,397 & 42,843 \\
\hline 18 & 18,164 & 197 & 5,082 & 10,283 & 48,072 \\
\hline 19 & 23,811 & -958 & 5,518 & 13,717 & 53,718 \\
\hline 20 & 52,392 & $-3,203$ & 6,267 & 39,468 & 69,715 \\
\hline All incomes & 9,252 & 56 & 2,646 & 3,727 & 33,016 \\
\hline
\end{tabular}

Source: Survey of Housing Spending (Statistics Canada 2009b). 
Table 6 - Decomposition of consumption-basis effective tax rates

\begin{tabular}{|c|c|c|c|c|c|c|c|}
\hline \multicolumn{8}{|l|}{ Vingtile of } \\
\hline adult-equivalent & & Federal & & & Provincial & & Grand \\
\hline total income: & GST & Other & Total & HST/RST & Other & Total & Total \\
\hline 1 & 0.029 & 0.017 & 0.042 & 0.032 & 0.030 & 0.059 & 0.101 \\
\hline 2 & 0.030 & 0.014 & 0.039 & 0.034 & 0.023 & 0.053 & 0.093 \\
\hline 3 & 0.030 & 0.014 & 0.039 & 0.033 & 0.024 & 0.053 & 0.092 \\
\hline 4 & 0.031 & 0.013 & 0.040 & 0.035 & 0.022 & 0.053 & 0.093 \\
\hline 5 & 0.032 & 0.015 & 0.044 & 0.038 & 0.027 & 0.062 & 0.106 \\
\hline 6 & 0.032 & 0.015 & 0.043 & 0.036 & 0.025 & 0.058 & 0.101 \\
\hline 7 & 0.033 & 0.015 & 0.044 & 0.038 & 0.026 & 0.061 & 0.105 \\
\hline 8 & 0.033 & 0.016 & 0.045 & 0.040 & 0.026 & 0.063 & 0.108 \\
\hline 9 & 0.033 & 0.015 & 0.043 & 0.037 & 0.024 & 0.059 & 0.102 \\
\hline 10 & 0.034 & 0.016 & 0.045 & 0.040 & 0.027 & 0.064 & 0.109 \\
\hline 11 & 0.034 & 0.015 & 0.045 & 0.038 & 0.026 & 0.061 & 0.106 \\
\hline 12 & 0.034 & 0.016 & 0.046 & 0.037 & 0.028 & 0.063 & 0.109 \\
\hline 13 & 0.034 & 0.015 & 0.045 & 0.037 & 0.026 & 0.061 & 0.106 \\
\hline 14 & 0.034 & 0.015 & 0.045 & 0.038 & 0.024 & 0.060 & 0.104 \\
\hline 15 & 0.035 & 0.015 & 0.045 & 0.039 & 0.025 & 0.061 & 0.106 \\
\hline 16 & 0.035 & 0.015 & 0.045 & 0.037 & 0.025 & 0.059 & 0.104 \\
\hline 17 & 0.035 & 0.015 & 0.046 & 0.038 & 0.025 & 0.059 & 0.105 \\
\hline 18 & 0.035 & 0.014 & 0.046 & 0.036 & 0.023 & 0.057 & 0.102 \\
\hline 19 & 0.036 & 0.014 & 0.045 & 0.037 & 0.023 & 0.058 & 0.103 \\
\hline 20 & 0.036 & 0.013 & 0.046 & 0.038 & 0.021 & 0.058 & 0.103 \\
\hline All incomes & 0.033 & 0.015 & 0.044 & 0.037 & 0.025 & 0.059 & 0.103 \\
\hline
\end{tabular}

Source: Authors' calculations, based on 2009 COMTAX and SHS data. See text for details. 
Table 7 - Indexes of tax progressivity

\begin{tabular}{|c|c|c|c|c|c|c|c|c|}
\hline Inequality & & & & & & & \\
\hline aversion & & Federal & & & & $\begin{array}{c}\text { Provincia } \\
\text { I }\end{array}$ & & Grand \\
\hline parameter: & GST & Other & Total & HST/RST & Other & Total & Total \\
\hline Low (e=0.5) & 0.100 & 0 & 0 & 0.100 & 0.100 & -0.200 & -0.100 & 0 \\
\hline Middle (e=1) & 0.100 & 0 & 0.100 & 0 & 0 \\
\hline High (e=2.5) & 0.400 & -0.200 & 0.200 & 0.500 & -0.600 & -0.200 & -0.300 \\
\hline
\end{tabular}

Notes: Blackorby-Donaldson index of tax progressivity, using the Atkinson inequality index and various inequality version parameters (e). A more negative index value indicates greater regressivity.

Source: Authors' calculations, based on 2009 COMTAX and SHS data. See text for details. 


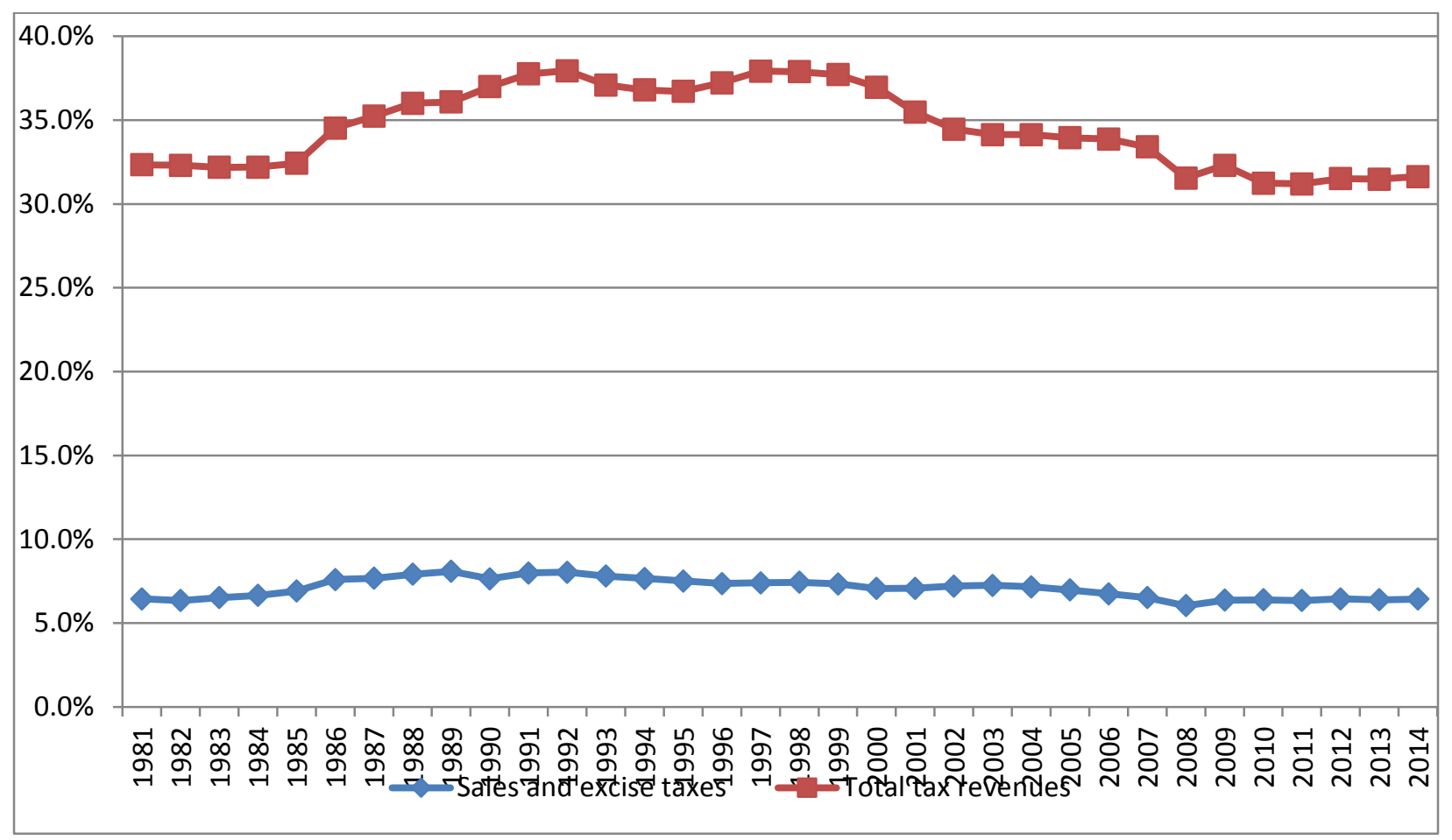

Figure 1. Total tax revenues and sales and excise taxes as per cent of GDP 


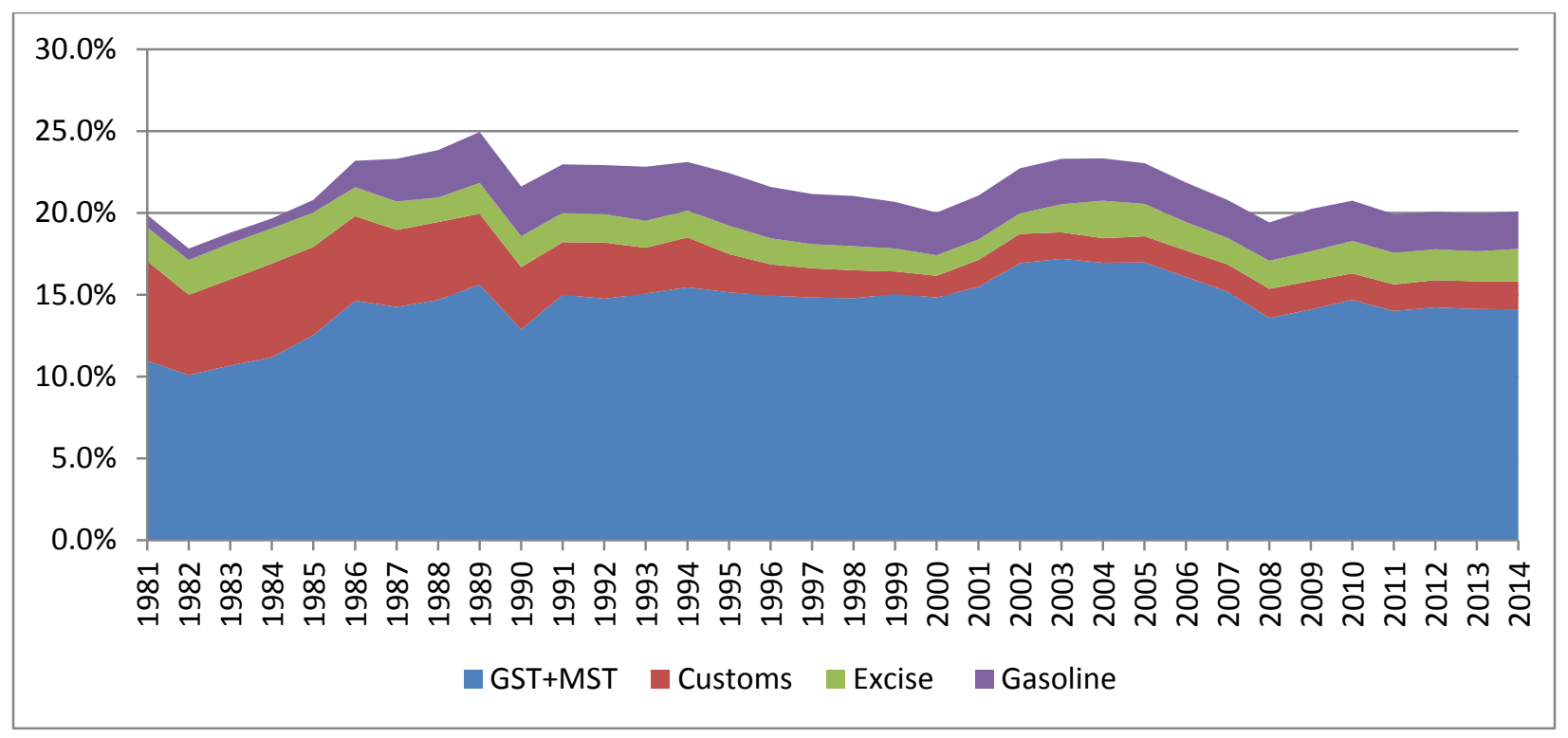

Figure 2 - Composition of Federal Sales and Excise Taxes 


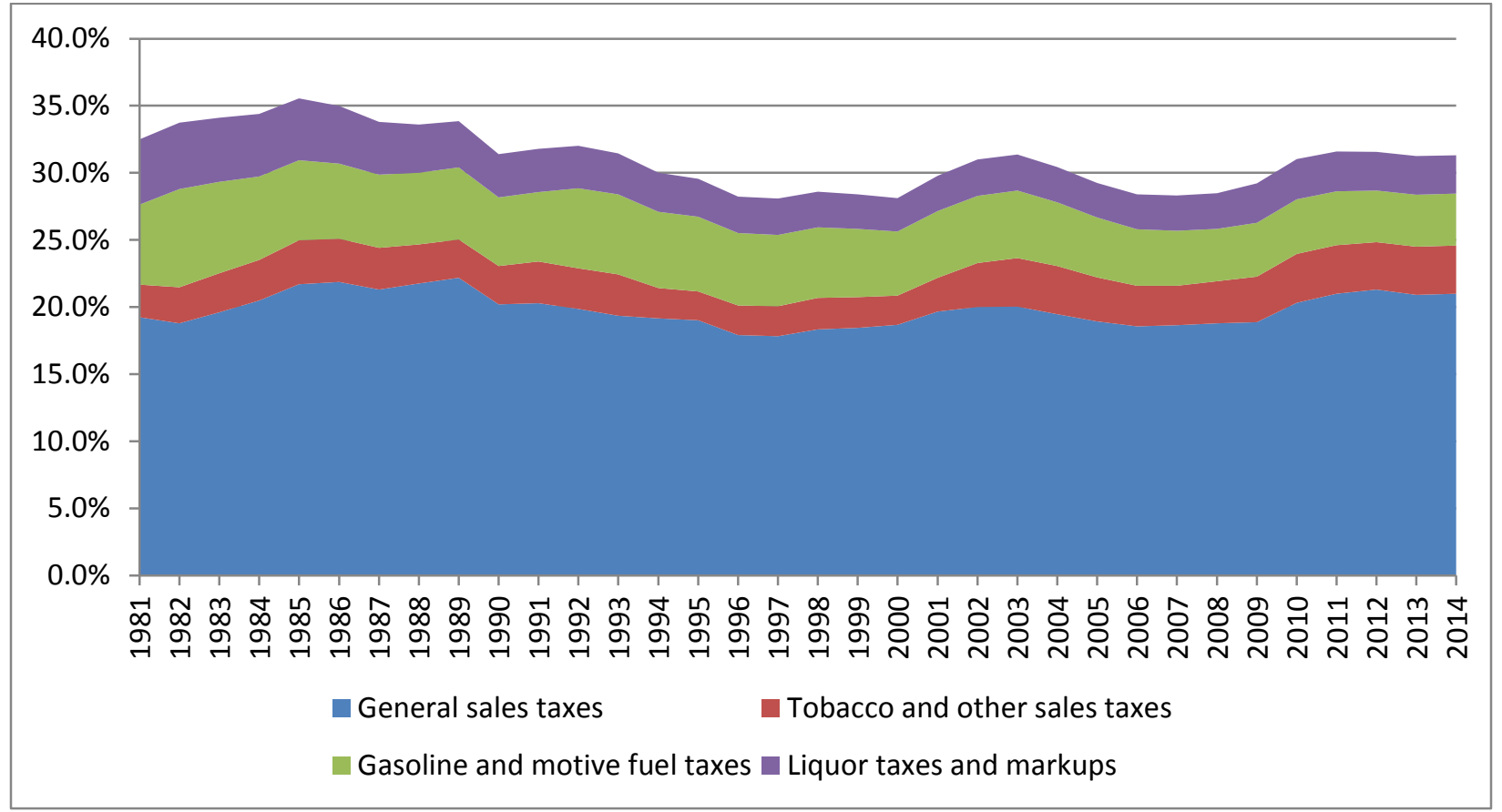

Figure 3 - Composition of Provincial Sales and Excise Taxes 


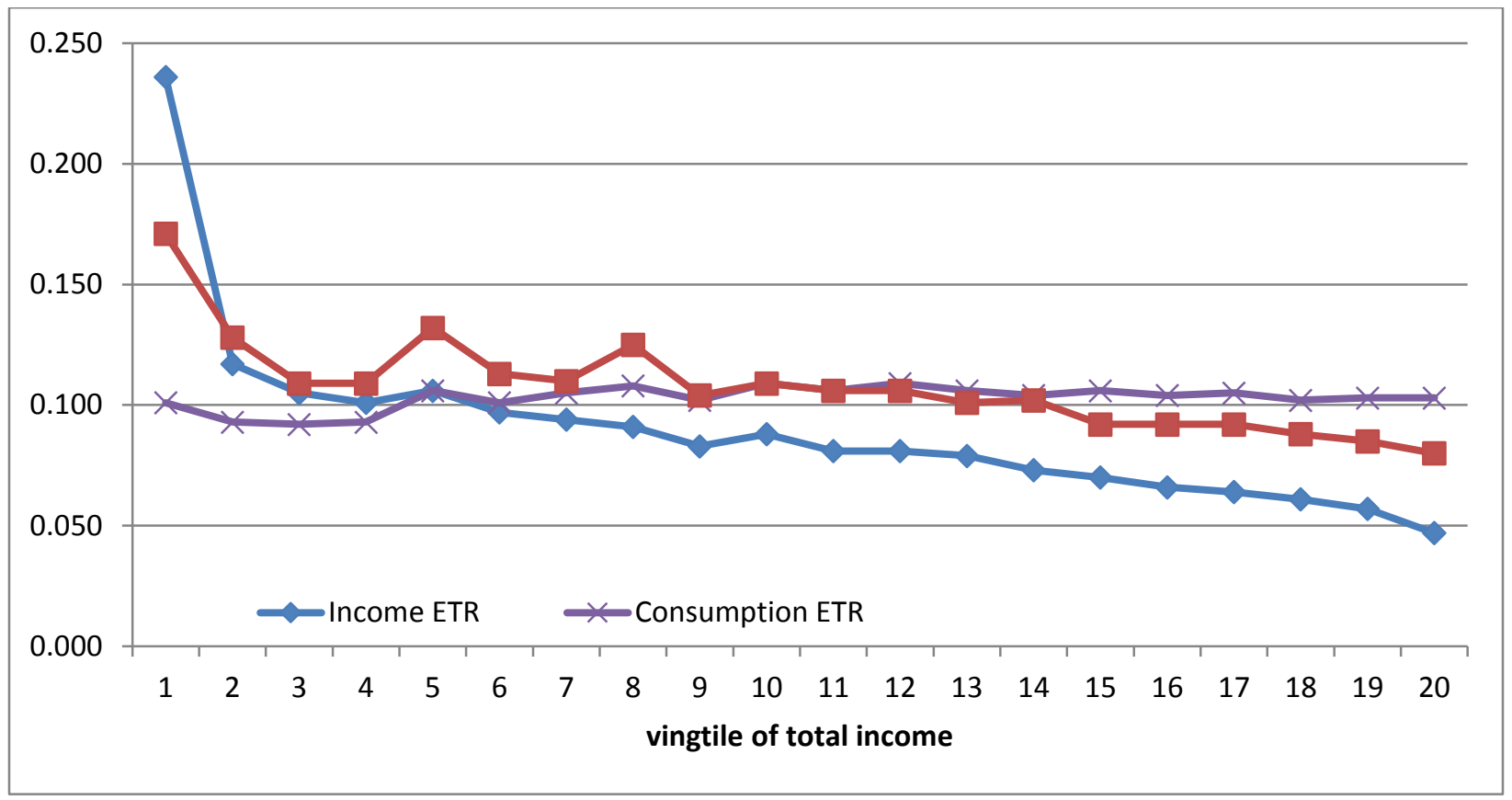

Figure 4 - Incidence of Sales and Excise Taxes 